\title{
POR UM MODELO HOLÍSTICO DE FORMAÇÃO DOCENTE
}

\author{
Marcos Gustavo Richter (UFSM) \\ richter@smail.ufsm.br
}

\section{RESUMO}

Este artigo apresenta as premissas e as bases de um modelo holístico, ou seja, globalizante, de formação de professores. Parte-se da crítica dos modelos tradicionais de formação continuada, que privilegiam o objetivo de "ensinar a refletir", mas se esquecem de que fazer docentes mudarem seu discurso sobre o ensino (ou seja, passarem a incorporar formas reflexivas de se pronunciar sobre questões didáticas) quase sempre não acarreta alterações na prática destes - prática esta que geralmente permanece tradicional, inconsistente e fortemente enraizada na cultura de ensinar-aprender com a qual os hoje professores cresceram na escola enquanto alunos. A presente proposta difere das anteriores em dois aspectos. Primeiro, não separa o binômio cognição-ação (fatores usualmente já integrados em formação de professores) da afetividade. Com isso, defendemos, entre outros pontos, que não pode haver formação de professores bem-sucedida se não comparecer, do lado dos docentes em formação, o genuíno desejo de mudar - de se aperfeiçoar profissionalmente e assumir a responsabilidade pelos seus esforços rumo a isso. Segundo, defende que a mudança começa, ao contrário dos modelos anteriores, não pela "modificação do discurso" e sim pela modificação voluntária da própria ação, apoiada não só pelo já mencionado desejo de mudar, mas também pela persistência na adoção do comportamento profissional alternativo de uma comunidade de formação que compartilha uma abordagem de ensinar-aprender consistente em termos teórico-práticos (com a qual esse professor venha a se identificar). A mudança do comportamento, por sua vez, acarreta a mudança dos afetos e das crenças àquele relacionados, na medida em que - numa visão holística, integral do ser humano - os conceitos que internalizamos e direcionam nossa conduta apresentam indissociavelmente essas três dimensões: comportamentos, crenças e afetos. O artigo termina direcionando o modelo para uma proposta de formação docente na área de português para estrangeiros e oferece alguns subsídios metodológicos.

\section{ESTADO DA QUESTÃO}

Ninguém ignora que se arrastam há décadas pesquisas acadêmicas preocupadas em encontrar respostas para o recalcitrante fracasso do sistema educacional em oferecer ensino de qualidade a todos. Nutti (2002) assinala que, não obstante o peso considerável dos fatores específicos da política educacional de cada país (organizacionais, infraestruturais e curriculares), o professor vem sendo considerado a figura-chave do processo educativo, tendo de responder pela natureza e qualidade deste último. A autora, apoiada em Mizukami, destaca também que, se por um lado é hoje incontroverso que docentes dão sustentação ao trabalho didático com crenças, valores e suposições inconscientes ou ao menos pouco articulados internamente e constroem de forma pessoal seu knowhow ao longo do exercício da docência, por outro lado a interpretação desses fatos tem sido obstaculizada pela existência de "uma variedade de referências conceituais e, conseqüentemente, diferentes formas de se conceber a construção de conhecimento e as formas específicas para se investigar essa construção" (ibid:01). Ora, se se impõe simultaneamente enfrentar o fantasma do insucesso educacional crônico e decidir sobre um referencial teórico dentre todo um leque proposto até hoje, acreditamos ser um critério básico legítimo de escolha a contribuição da teoria para a eficácia (trans)formadora da competência docente.

Em havendo mais de uma teoria que se mostre promissora para o trabalho de formação continuada, propomos acrescentar um critério adicional: o poder explicativo, tanto dos fatos já conhecidos sobre o pensamento prático docente, quanto das condições sócio-psíquico-ecológicas de resistência e modificação desse pensamento. A literatura corrente tem-se mostrado em geral satisfatória em relação ao primeiro aspecto; mas infelizmente tem deixado a desejar no segundo. Dito de outra forma, pode-se constatar que, não obstante o considerável trajeto até agora percorrido nas pesquisas sobre formação continuada (Candau, ap. Nutti, op.cit.), persiste uma preocupante e não menos intri- 
gante distância entre os esforços acadêmicos e institucionais pela melhoria da qualificação do ensino e os auspícios de mudança concreta, inequívoca e irreversível no perfil de desempenho dos professores.

Cabe então perguntar: o que vem sustentando esse cenário de frustração crônica, o que tem permanecido como obstáculo ao desenvolvimento docente? Podemos explorar possíveis respostas examinando sucintamente as tendências mais importantes em formação continuada nos últimos anos, bem como suas limitações epistêmicas e metodológicas, e esboçando saídas viáveis para esse impasse. Grosso modo, a formação continuada vem-se desdobrando na esteira de duas vertentes principais, denominadas por Schön (ap. Perez Gómez, 1995) de racionalidade técnica e racionalidade prática. A primeira, consonante com as tendências tradicionais do pensamento pedagógico, considera que os professores não passam de técnicos qualificados cujo papel consiste em implementar em seus contextos, com a requerida exatidão e fidelidade, teorias e preceitos formulados em gabinete por pesquisadores da Academia e pelos demais especialistas da área. Fica evidente, não só em termos práticos, mas também políticos e ideológicos, a dicotomia - e assimetria - entre, de um lado, os que estudam, pesquisam, desenvolvem, "conhecem" antecipadamente os problemas e perguntas que emergem no cotidiano escolar; e, de outro, os que desamparada e avidamente ficam à mercê de respostas prontas (as assim-chamadas e tão disputadas "receitas") e baseiam-se na intuição e experiência prática informalmente acumulada para lidar com situações que se lhes afiguram complexas, conflitantes e não raro imprevisíveis.

Ainda hoje, na mídia, é possível acompanhar artigos em publicações vulgarizadoras endereçadas a professores, nas quais estes se acham representados, nas entrelinhas, como trabalhadores a quem não importa investigar o que fazem e por que o fazem, acometidos por vezes de "boas idéias" surgidas em geral por obra de um afortunado e casual lampejo de inspiração - e atormentados cronicamente por dúvidas sanadas de maneira paternalista e providencial por especialistas que "sabem", mesmo antes de formuladas, as perguntas que aqueles Ihes endereçariam. Numa silenciosa apologia à subalternidade, constrói-se um cenário supostamente natural em que os docentes personificam proletários expropriados de seu saber, fazer e ser, infantilizados nas relações de produção e desprovidos de voz própria. Claro que a leitura constante de artigos deste teor contribui para reforçar subliminarmente este jogo de posicionamentos identitários recíprocos a nosso ver antiemancipatórios.

Para agravar esse quadro, campanhas de incentivo ao voluntariado desfiguram e esvaziam as especificidades da preparação do educador, na medida em que convertem o contexto escolar e as competências didáticas em uma verdadeira terra de ninguém que qualquer um se sente autorizado a invadir como "grileiro" do ensino a fim de dar seu palpite. Diante disso, a opinião pública - indiretamente presente na cultura de ensinar e aprender em vigor - acaba por não compreender no que consiste exatamente esse saber específico, ao mesmo tempo inefável e supérfluo em seu semblante, associado ao papel de professor.

A segunda tendência em formação continuada, denominada de racionalidade prática, tenta escapar dessa perspectiva dicotômica e assimétrica, ao ultrapassar a relação mecanicista, reducionista e linear entre o conhecimento estabelecido academicamente como científico e as bases teóricoprocedurais da organização da rotina de trabalho escolar. Parte da premissa de que os professores dispõem em sua mente de esquemas mentais, não totalmente conscientes ou articulados, capazes de influenciar ou mesmo determinar o modo como pensam e se comportam no ambiente de trabaIho. Este saber, apesar de pouco consistente, já viabiliza a constituição de um contexto colaborativo no qual membros da Academia e profissionais do ensino unem esforços para equacionar e solucionar problemas emergentes da própria prática cotidiana, no ambiente específico em que ela se desenrola. Neste caso, contrariamente à vertente da racionalidade técnica, as crenças dos professores não são desqualificadas ou mesmo descartadas a priori, e sim integradas e enriquecidas conceitu- 
almente, ao longo de um trabalho de co-reflexividade metódico e orientado. Ou seja, o professor passa a ser um sujeito reflexivo e crítico, capaz de construir na interface ação-reflexão uma compreensão mais bem fundamentada dos processos didáticos e uma maior integração entre a teoria e a prática.

O modo como se apresenta esta segunda proposta ainda acrescenta como dividendos o fato de acenar com o augúrio habermasiano de transformação política das instituições a partir do trabalho lento de propagação da prática dialógico-crítica de profissionais em condição de sujeição a decisões das camadas sociais dirigentes e seus prepostos. Sem dúvida, o aspecto particularmente sedutor desta perspectiva reside, ao menos em parte, na necessidade que acomete o docente de libertar-se de uma sobrecarga discutível de responsabilidades de natureza sistêmico-institucional e tornar-se senhor da fatia de prerrogativas que lhe cabe por formação - competências essas que sente necessidade de definir com exatidão, de que lhe falta apropriar-se e que lhe cabe administrar como um território privativo de sua profissão, estabelecendo: a) definição e delimitação de atribuições; b) critérios de habilitação e credenciamento; c) especificações de práticas consideradas condizentes com os ditames e o nível de desenvolvimento da ciência e da técnica; d) princípios de ética profissional para seus membros; e) formas defensivas de corporativismo contra possíveis ingerências abusivas externas; e f) amparo legal contra o eventual exercício ilegal ou irregular da profissão por pessoas não habilitadas.

Entretanto, a perspectiva reflexivo-crítica da formação continuada colide com atravancamentos de natureza cultural e psicossocial. Reynaldi (1998) assinala que a tradição de ensinar determina as crenças sobre ensino-aprendizagem de línguas que sustentam a conduta docente. Dito de outro modo, esta última alicerça-se, em grande parte, nas premissas, teorias, valores e mitos concernentes às diversas variáveis do trabalho didático - tais como o ensino, o conteúdo, o currículo, os alunos, o estabelecimento de ensino e o processo de aquisição - e introjetados, como formas tácitas de pensar, julgar e proceder, pelo (agora) professor ao longo de sua extensa trajetória pregressa de aluno, à qual se soma a experiência prática de ensino acumulada em geral de modo solitário, informal, assistemático e pouco refletido. Em suma, professores ensinam como foram ensinados: sua prática está desde sempre "maculada biblicamente" por um pecado original herdado através de gerações.

Essa situação de inércia imposta pela prática corrente de ensino é tão marcante que pode vir até a sobredeterminar a própria formação universitária, quando existir, quer formalmente, quer informalmente recebida. Chimim (2003), ao investigar as crenças de professores no contexto de uma franquia, reúne consideráveis indícios de que é exatamente isso que tende a ocorrer. No caso estudado, o conhecimento prático adquirido pelos docentes em suas experiências pregressas de aluno e professor, acrescido da forma como vinham percebendo e equacionando comportamentos, teorias e representações mútuas, apresentava o poder de nivelar as condutas de dois tipos bem diferentes de professores de língua estrangeira. A saber, os empregados meramente por fluência adquirida durante estadia em outros países, e os contratados mediante comprovação de formação superior na área.

A tradição pedagógica, na medida em que reflete os conceitos sobre ensino-aprendizagem predominantes em determinado bloco histórico, atua como um "escudo" de saber consensual que fornece suposta salvaguarda ao docente contra a notória precariedade de sua formação e a limitada credibilidade de sua identidade social. Frente a isso, nada tem de surpreendente a constatação reiterada e frustrante de que essas teorias de ensinar-aprender - enraizadas no recôndito da mente dos professores em suas histórias de vida - resistem fortemente à mudança, malgrado heróicas e sempre louváveis tentativas neste sentido. Nada de espantoso, nada de esotérico. Pois, na medida em que o processo reflexivo crítico se processa nos interstícios da prática profissional, ao redor de uma mesa ou sobre o papel, como no caso dos depoimentos escritos, o discurso do professor em 
formação torna-se uma prática para-institucional. Deste modo, pode ser acionado de um lugar seguro a partir do qual a articulação metacognoscente de conceitos e relações entre conceitos, mais do que oferecer oportuna preservação à auto-imagem habitualmente exposta e vulnerável aquém dos portões da escola, concilia sob alguns aspectos esta representação identitária com certas exigências superegóicas da Academia.

A conseqüência não se faz esperar: o tiro sai pela culatra, dado que essa tentativa de conciliação acaba por manifestar um sujeito-docente dividido entre uma ordem discursiva que o representa comprometido de forma metacognoscente com o saber acadêmico e outra que, dispersa na conduta professoral, permite entrever procedimentos que, precisamente por seu caráter de automatismos, deixam de fazer parte do campo perceptivo do sujeito. O resultado, sobejamente conhecido do pesquisador que trabalha com formação continuada, é, para dizer o mínimo, curioso: o depoimento do docente mostra todo um esmero em discutir teorias e boas intenções, como que "posando" de academicamente ilustrado; ao mesmo tempo, revela-se refratário às evidências, seja tão-somente relatando superficialidades comportamentais no contexto de ensino, seja pronunciando-se como juiz dos problemas (também via de regra comportamentais) dos alunos. Interpelados pelo coordenador do programa de formação continuada a explicitarem as decisões tomadas quanto a input, objetivos, arquitetura das aulas e das tarefas, resultados esperados e resultados obtidos, bem como os respectivos fundamentos e hipóteses explicativas, os docentes silenciam. Ou melhor, retornam como um sintoma na fala - às superficialidades de espectador e de juiz. Cumprida a reflexão crítica, feita, portanto, a "lição de casa", os professores estão em paz com a Academia e...com seus automatismos didáticos. $\mathrm{E}$ a vida continua.

Para darmos um exemplo da literatura mais recente, um dos sujeitos da pesquisa de Chimim (op.cit.) materializava claramente algumas das perplexidades mais comuns dos pesquisadores em formação continuada. Graduado, exercendo a docência e ainda a coordenação de curso na unidade da franquia investigada, ele dispunha das condições básicas para a reflexão-na-ação e a resolução de problemas e se mostrava efetivamente capaz disso, segundo observações da autora. Mas não estava consciente do que fazia: faltava-Ihe a operacionalização conceitual dessas ferramentas de desenvolvimento docente, ou seja, não se manifestava, ao longo do trabalho de intervenção reflexiva proposto, a união produtiva do pensamento prático com o saber teórico no exercício profissional. Como resultado, o sujeito apresentava dificuldade não só para justificar consistentemente o que fazia no exercício de seus cargos (ainda que viesse a ser adequado), mas também para redimensionar oportunamente algum aspecto de sua prática. Numa outra figuração, o salto do discurso reflexivo para a conduta em-serviço assemelhava-se à repentina transmutação ficcional de Dr. Jekyll em Mr. Hyde.

Isso tudo, a nosso ver, contribui para relativizar (mas sem desqualificá-la, bem entendido) a alegação de que a reflexão crítica em si mesma autoriza um prognóstico otimista de mudança da conduta docente e de suas bases cognitivas. Inclusive a experiência de quase uma década de pesquisa do presente autor vai ao encontro dessa atitude de comedimento.

\section{EM BUSCA DE ALTERNATIVAS}

A esta altura, caberia perguntar que equívocos poderiam residir nas entrelinhas da proposta reflexivo-crítica, funcionando como empecilhos para a mudança. Para tanto, começamos partindo de algumas pistas fornecidas por um dos discursos norteados por essa abordagem. Liberalli (1999), na defesa da reflexão crítica como condição suficiente para deflagrar a transformação (inseparável da emancipação) da conduta do profissional de ensino, assim se manifesta:

A visão de reflexão abordada neste estudo centra-se nessa proposta de reflexão crítica (...) $\mathrm{Na}$ verdade, refletir dessa forma seria uma possibilidade de 
emancipação, uma vez que não haveria uma simples sujeição às teorias formais, mas uma confrontação entre prática e teoria, e uma emancipação pela possibilidade real de escolha (...) (p. 04)

Em outro trecho, ao abordar o diário como instrumento para potencialização da reflexão crítica, a autora considera que ele

possa ser um instrumento para a transformação do indivíduo uma vez que, através dele, o sujeito tem a oportunidade de escrever sobre sua ação concreta e também sobre teorias formais estudadas. Além disso, por sua característica escrita, o diário permite um distanciamento e organização do pensamento, que poderá servir como contexto para o desenvolvimento da reflexão crítica. (p.03)

Se confrontarmos estes argumentos com os de Nutti, Reynaldi e Chimim (para ficarmos só com estes autores), Liberalli sugestivamente tende a superestimar as condições psíquicas reais do professor para autodeterminar as coordenadas de seu fazer didático, na medida em que, nos trechos acima, faz equivaler desenvolvimento da reflexão escrita a liberdade de escolha do comportamento. Como já pudemos discutir, os fatos não parecem esboçar um quadro assim simples, pois este mesmo comportamento profissional, ao menos em parte, não decorre de escolhas puramente racionais. Perrenoud (1997) retoma um termo de Bourdieu, "habitus", para designar um "pool" de esquemas conexos, refratários à modificação pelo profissional, em que se entrelaçam rotinas supergeneralizadas e improvisação intuitiva para compor o que o professor é capaz de fazer sem ter como explicar por que motivo, de que maneira ou em que bases teóricas. Esse referencial difuso permiteIhe, é certo, enfrentar a complexidade do ensino real, mas ao preço de lhe dificultar a estruturação global da prática em termos teoricamente consistentes. Isso, por sua vez, acaba impedindo-o de considerar outras soluções possíveis que poderiam ser testadas, talvez com êxito, no mesmo contexto. Conseqüentemente, mesmo um profissional da educação reflexivo, provido das melhores intenções e comprometido com a mudança, ao voltar à sala de aula e se ver diante de situações inesperadas, não raro reflui ao comportamento que herdou da tradição de ensinar.

Outra objeção a ser feita, a rigor a ambas as abordagens de formação continuada discutidas, é justamente sua pretensão de racionalidade. Neste quadro, a cognição ativa esvazia-se dos aspectos afetivos da experiência, resultando em uma intelectualização artificial e forçada da reflexão, prejudicial tanto para a motivação em mudar quanto para a superação das resistências mais profundas à mudança. A prática reflexiva, não obstante ter nascido moral com Dewey e se tornado posteriormente sócio-política com Carr e Kemmis, lamentavelmente tem-se posicionado num incômodo "fio da navalha" quanto a seu preciso estatuto e objetivos. Como constatam Leitch e Day (2000), esta prática social, caso privilegie esses últimos aspectos, corre o risco de se ater somente à conduta profissional e deixar de trabalhar a reconstrução de identidades sociais. Já a reflexão voltada apenas à introspecção do sujeito situado, com o intuito de explorar a autoconsciência e o crescimento pessoal decorrente, tende a esvaziar a cognição ativa de seus componentes profissionais específicos.

O resultado da primeira perspectiva, conforme os autores, é a conhecida frustração de, ao final, não obter a tão sonhada transformação de crenças, procedimentos e valores docentes, além do refluxo ao recalcitrante habitus do professor. Por outro lado, o resultado da segunda não passa de um benefício em forma de terapia que, mesmo atenuando o mal-estar docente e outras formas disfuncionais de vida psíquica, não pode mais ser considerada pesquisa. Lembremos que o binômio reflexãoação, acompanhado de uma sucessão de ciclos de resolução de problemas, desemboca na já conhecida abordagem de pesquisa-ação, desde que seu foco seja uma inadequação entre os procedimentos didáticos e/ou suas bases conceituais e os resultados da prática profissional hipoteticamente atribuídos a esta inadequação. Ainda segundo Leitch e Day, uma possível solução para este impasse residiria em um trabalho de formação continuada centrado nos valores do sujeito, os quais 
jamais se separam quer de sua reflexão quer de sua ação. Nesta nova perspectiva, um aspecto central do trabalho reflexivo metódico para os professores consiste no resgate da relação entre a cognição e a emoção ou sentimento, evidente no questionamento socrático típico desta proposta: Quais são os meus valores enquanto profissional do ensino? O que faço para assumir os valores que associo ao meu papel de professor (ao meu modo de ser professor) em meu contexto? Como vivo meus valores na prática cotidiana?

Fica claro que um enquadramento desta natureza implica considerar o sujeito-docente na íntegra: cognição + comportamento + sentimento. Isso, por seu turno, vai ao encontro da necessidade de alterar a concepção clássica de pesquisa-ação, que passa de metodologia a abordagem. E, a partir do momento em que se dá este deslizamento epistemológico, a pesquisa-ação torna-se a própria prática social cuja mediação é o interdiscurso dos envolvidos no empreendimento pedagógico. Ou, dito de outra forma, a pesquisa-ação contribui como fundo organizador do contexto em que o professor situa, ao mesmo tempo, seus conceitos, seu fazer e seus valores, emanados do jogo de representações identitárias que põe em jogo quando assume seu papel.

Leitch e Day (op.cit.) advertem que, em todo trabalho de reflexão crítica, dificilmente alguma mudança visceral e duradoura poderá ter lugar sem o acesso aos substratos emocional e imaginário; ao contrário, um trabalho que leve a enraizar a reflexão nas camadas mais profundas da psique as crenças centrais do docente sobre si e seu trabalho, traduzidas em valores e sentimentos pode abrir as portas para um eu-docente mais ajustado às condições objetivas de seu exercício profissional. Nas palavras dos autores (p.188-9):

Sem o acesso às emoções, não há oportunidade para liberar sentimentos e sem liberação não há lugar para reavaliação. (...) Anterior avaliação do impacto de tais abordagens de reflexão docente (...) tem indicado que eles [sentimentos] não apenas propiciam ao indivíduo oportunidades de reavaliação profunda, mas também têm levado a poderosas mudanças nas práticas dos professores. (tradução nossa) ${ }^{1}$

Dentre os autores que defendem a conceituação da Pesquisa-Ação como abordagem e, simultaneamente, um enfoque holístico na formação continuada (ou seja, resgatando todas as dimensões do psiquismo do eu-docente, inclusive a afetiva), merece destaque Feldman (2002), que propõe reequacionar a Pesquisa-Ação nos moldes de uma visão existencialista do profissional da educação. Segundo ele, as ações, intenções, crenças e outras facetas do professor são manifestações de suas maneiras de serem professores. Isto significa que tais aspectos da vida psíquica, a rigor, não se "somam" a um "eu genérico" que num dado momento se posiciona num contexto para desempenhar determinado papel (digamos, de docente). Constituem, na verdade, um todo indissociável que configura uma das diversas maneiras pelas quais uma pessoa é e pode ser — vale dizer, um de seus vários eus. Trata-se, como podemos notar, de uma concepção relacional da pessoa, segundo a qual não há um conjunto inerente de características de um sujeito, independente do contexto; assujeitarse implica tomar características daquilo que precede e determina o sujeito: a própria relação humana, social, histórica, cultural, contextualizada.

Uma conseqüência dessa perspectiva existencial é que, para que docentes possam mudar (para que sua prática se altere de modo duradouro), torna-se necessário mudarem suas formas de serem

1 Without access to the emotions, there is no opportunity to release feelings and without release there is little room for re-evaluation. (...) Early evaluation of the impact of such approaches to teacher reflection (...) has indicated that they not only provides the individual with opportunities for profound re-evaluation, but have also led frequently to powerful changes within the teachers' practices. 
docentes, ou seja, é preciso transformarem sua vida psíquica de docentes como um todo: comportamento, crenças, valores. Em função disso, a pura e simples reflexão freqüentemente resvala, de maneira paradoxal, para a manutenção do status quo ao invés de transformá-lo, porque esse procedimento pode (até freqüentemente) degenerar em um exercício de retomada constante de significações a partir de uma perspectiva fechada e rígida - de um olhar que não é relançado de outro lugar.

As premissas de uma perspectiva existencial da reflexividade docente, que, conforme Feldman, permitem redimensionar essa visão subjetiva sobre a experiência complexa de ser professor, incluem reconhecer que:

1. Pessoas são "situadas", no sentido de constituírem uma espécie de nó relacional, não apenas em uma rede de objetos, eventos e outras pessoas, mas também em uma rede individual e social de acontecimentos emanando do passado, projetando-se para o futuro e incorporando instituições, tradições, crenças e valores constituídos e em constituição no referido bloco histórico;

2. O eu emerge da experiência, em termos sartreanos de não ser algo pré-determinado, e sim construído ao longo de (e por meio de) opções, decisões que tomamos em nossas experiências. Em outras palavras, nossa identidade jamais está pronta, muito menos consiste em algo forjado por terceiros em que somos obrigados a "caber" como leito de Procusto. Ao contrário, é sempreemergente a partir de nossas ações deliberadas, em relação às quais o eu relaciona-se reflexivamente ao longo do tempo. Nesse trabalho de significa-se nas/pelas suas escolhas em agir, o sujeito deve moldar seu quadro de valores e mesmo lapidar-se a si próprio, ao escolher constantemente que tipo de pessoa ele é momento a momento - como configura-se e realiza-se, como se representa na prática pelo que faz, como e por que o faz. Sua "essência" passa a ser a identidade que define para si mesmo ao viver.

3. O sujeito é livre para decidir, porém a margem de liberdade (e de escolha) é finita, limitada. Mais precisamente: liberdade, no presente enfoque, não equivale a poder agir sem limites; também não se confunde com autonomia - aqui conceituada como a consciência das próprias intenções. Ser livre, mais do que ser autônomo, é exercer a prerrogativa de conceber alternativas, de compartilhar com outros um projeto de mudança; é, enfim, ultrapassar o dado e olhar as coisas como se pudessem ser de outra maneira. Claro que, conceituada como ultrapassagem escolhida, a liberdade é situada, limitada às estruturas existentes e ao leque viável de modificações que aquelas comportam. Não obstante, imbrica-se com a criatividade do ser humano e aplica-se simultaneamente a este e a seu entorno sócio-histórico.

Em síntese, esta visão de formação continuada convida o professor a exercer a liberdade de se autodeterminar no papel desempenhado, dentro das limitações impostas pela realidade, por meio da experiência resultante do exercício constante de optar e situando-se nas ações escolhidas em função de como deseja representar-se para si e para o outro na função social exercida. Proposta cujo mérito não se esgota somente na superação da idéia de um eu-docente que "reflete criticamente" reduzindo sua vida profissional à dimensão epistêmica, amputando as demais (alética, deôntica, axiológica). Mas acrescenta o redimensionamento das variáveis da formação profissional como um todo em um paradigma holístico. Disso decorre que, ao se repensar a formação docente inicial e continuada, impõe-se um novo enquadramento, que aqui propomos: um Modelo Holístico de Formação Docente. Neste, os instrumentos a serem utilizados para a análise do discurso professoral deverão equacionar o eu-docente em termos de uma representação identitária situada entre outras e mediada pelas singularidades discursivas associadas (Gee, 1999). Na mesma vertente, a indissociabilidade entre o eu e seu entorno sócio-histórico-cultural (ou entre a mente e seu ecossistema simbólico) solicita um enfoque sistêmico, perfeitamente contemplado pelo paradigma da complexidade. 
Além disso, em um Modelo Holístico, parte-se da idéia de que o sujeito se constrói a partir de um compósito estruturado de crenças, desejos, valores, intenções, planos e condutas nos remete a uma teoria unificadora do funcionamento da mente (D'Andrade, 1987), bem como converge à tese de Leitch e Day (op.cit.) segundo a qual somente transformando os aspectos emocionais do sujeito (inclusive seus valores) é que este poderá ter alguma chance de enxergar as facetas de sua experiência de vida docente de outro modo - requisito essencial para o exercício da liberdade, da criatividade, da mudança. E também para a formação de conceitos mais compatíveis com a interface teoria-prática. É conhecida, a esse respeito, a posição ambígua da psicanálise em face da educação. Após um breve período inicial de "colonização" da educação pelos princípios freudianos, a vertente lacaniana assumiu inequivocamente a impossíbilidade de resolver problemas na área educacional com o emprego de conceitos freudianos e mesmo lacanianos. A teoria dos quatro discursos de Lacan propõe a máxima dos "quatro impossíveis" - governar, psicanalisar, fazer-se amado e educar —, sendo que o impossível do educar reside (entre outros aspectos) no fato de não haver educação sem ações diretivas, enquanto que a psicanálise só subsiste como prática e como campo discursivo na medida em que um dos pólos abdique de sua condição de sujeito (o do analista), para que no outro emerja uma subjetividade genuína (a do analisando). Em anos de experiência em formação inicial e continuada, foi-nos possível comprovar a quase impossibilidade de trabalhar de forma profícua com a reflexividade docente sem efetuar intervenções na cognição dos professores envolvidos. Além disso, sem que eles compareçam ativamente no contexto de formação com seu desejo de participação ativa e espontânea, mudanças ou não ocorrem ou somente deixam entrever possibilidades futuras, ainda que na forma de interrogações.

Esse quadro pouco alentador suscitou alterações viscerais tanto no referencial teórico (uma visão holística, relacional e complexa da formação docente) quanto nos procedimentos metodológicos adotados - que impuseram, mais realisticamente, uma prática social colaborativa, focalizada em resolução de problemas, como antes, porém, a partir deste momento, também diretiva, pois esta se nos afigura uma das condições básicas para a reeducação do próprio profissional. Genericamente, o roteiro básico utilizado, tipo "problem-solving", consiste em, ou equivale à seguinte proposta:

I. Delimitação de um problema

II. Equacionamento claro dos diversos aspectos pertinentes do problema

III. Estabelecimento de metas específicas para superar o problema

IV. Avaliação de obstáculos (na forma de crenças distorcidas) que se interpõem entre o reeducando e o estado de coisas desejado

V. Levantamento de evidências (fatos concretos, observações palpáveis) relacionadas a esses obstáculos e o confronto delas com o sistema de crenças do reeducando, a fim de avaliar se os esquemas cognitivos deste último fornecem ou não sustentação para essas evidências; havendo inconsistência, exploração de outras formas de concepção ou abordagem dos fatos problemáticos

VI. Elaboração conjunta de um plano de ação para testar alguma(s) dessas outras formas de concepção ou abordagem dos fatos problemáticos, eventualmente pondo à prova premissas, conclusões ou raciocínios mal estabelecidos

VII. Com base nos resultados da ação planejada e realizada, reflexão avaliativa com o intuito de reconhecer distorções cognitivas e/ou impropriedades conceituais do reeducando

VIII. Implementação de ações corretivas da cognição visando a atenuar ou corrigir distorções

IX. Por meio da continuidade das ações corretivas, intervenções no circuito pessoal reforçativo de comportamentos disfuncionais do reeducando

$\mathrm{X}$. Aquisição gradual, pelo reeducando, de know-how para a resolução de problemas, com a finalidade de diminuir a incidência do retrocesso a comportamentos inadequados, frente a novas ocorrências de situações incômodas.

Em função destas necessárias readequações, o presente estudo procurará basear-se na abordagem conhecida como socioliteracy studies (estudos de socioletramento: cf. Lankshear, 1999; Gee, 1996, 1998, 2000). Em Gee (1998), esta abordagem se mostra claramente em convergência com as 
premissas básicas da Pesquisa-Ação e da Terapia Cognitiva, quando o autor argumenta que discursos, tanto como mediadores de práticas sociais quanto como práticas sociais em si, são "enactivos", ou seja, consistem em formas de atividade destinadas a coordenar aspectos extralingüísticos da vida social (coordenações de ações, para empregar um termo de Maturana) e a autocoordenaremse em seu caráter específico de sistemas sociossemióticos (coordenações de ações de coordenações de ações, novamente segundo Maturana). Ora, esses elementos da vida social, indissociáveis da vida psíquica na medida em que esta se constitui a partir daqueles, distribuem-se por todas as dimensões desta vida psíquica. Pessoas, coisas, artefatos, símbolos, instrumentos, tecnologias, ações, interações, tempos, lugares, formas de falar, ler, sentir, pensar, valorar, entre outros, fazem parte das percepções, crenças, saberes, esquemas, sentimentos, desejos, intenções, condutas, logo das pessoas holisticamente consideradas - um todo cognitivo-afetivo-comportamental. Exatamente nos moldes das abordagens reeducativa da Terapia Cognitiva e existencialista da Pesquisa-Ação.

Gee também defende que "mundos sociais" - universos de experiência, de crença, de valoração são criados, mantidos e negociados por meio de comportamentos (orientados aos objetos da cultura) destinados a obter dos outros um aval de reconhecimento, de significância. Em outras palavras, todo ato de apropriação do espaço do discurso implicita uma tentativa sempre renovada de conquistar o acolhimento do outro, seja em termos do acolhimento das representações sociais e contextuais que o sujeito seleciona para adoção (processos identificatórios), seja em termos do acolhimento da(s) própria(s) prática(s) social(is) configurada(s) pelos discursos acionados. Respectivamente, ser acolhido como membro de uma comunidade discursiva (o imaginário) e ser reconhecido como apto a participar das práticas e relações sociais dessa comunidade discursiva (o simbólico). $\mathrm{Na}$ falta de um ou ambos os reconhecimentos, o sujeito responde organicamente com um quadro sintomático disfuncional (o real). E sob mais este aspecto podemos estabelecer aproximações dos estudos de socioletramento (paradigma sócio-cultural da análise do discurso) com as premissas da psicologia cognitiva em suas implicações reeducativas.

Cabe ainda examinar outro ponto da abordagem sócio-cultural do discurso antes mencionado, a questão da significância. Na medida em que esta implica conceber ou representar coisas (ou manifestar recusa a concebê-las ou representá-las) de determinada maneira (aquela com que nos identificamos), a significância envolve uma operação semiótica de especificação - dado um contexto como "fundo", selecionar uma dentre diversas possibilidades de orientar um fluxo interpretativoenactivo, descartando ou apagando as demais. Ou seja, podemos equacionar numa relação de equivalência: significância = relevância. $\mathrm{O}$ que significa, na presente discussão, essa sobreposição semiodiscursiva? Que: a) se nos propusermos a abordar o discurso, não em termos conteudísticos (exclusivamente), e sim em termos de suas marcas formais constituidoras-especificadoras; e b) se concebermos o texto, não como objeto imanente (isto é, dotado de pregnância interpretativa plena), e sim como correlato material do discurso na forma de "mapa" de pistas sinalizadoras para a interpretação num dado contexto, seremos levados a admitir que o discurso é uma construção social de sentidos indiciados pelo seu suporte semiótico - o texto (no sentido amplo, englobando o verbal e outros códigos paralelamente presentes).

A metodologia de eleição que, a nosso ver, consegue satisfazer estas expectativas é o paradigma indiciário, que se opõe ao paradigma galileano (concepção positivista-iluminista de ciência) no sentido de corresponder a um conjunto de práticas e campos específicos de conhecimento cuja ferramenta epistêmica é a conjectura. Este paradigma está voltado à construção de conhecimento balizado não pela exatidão ou pelas proposições genéricas provadas (como ocorre com as ciências exatas e/ou experimentais), e sim por inferências, hipóteses explicativas ou conclusões provisórias autorizadas por premissas provavelmente mas não necessariamente verdadeiras. Essas premissas em geral são formuladas a partir de dados fornecidos pelo contexto que serve de fundo para o recorte, a intelecção e o controle de consistência dos fatos investigados. 
O paradigma indiciário também se caracteriza por uma abertura às justificativas utilizadas pelo pesquisador para a escolha de uma solução conjectural dentre outras: maior probabilidade, maior pertinência ao recorte temático ou teórico do problema, maior simplicidade, maior consistência e esteticidade do edifício conceitual em construção, etc. Contrariamente ao paradigma galileano, não se busca aqui (ou melhor, não é uma condição sine qua non para a aceitação dos resultados) uma correspondência e concordância inequívocas entre o discurso de sustentação da prática científica e os referentes materiais do universo objetivo.

Finalmente, enquanto o paradigma galileano acentua a importância do generalizável, mensurável, independente do contexto, o paradigma indiciário prioriza o irrepetível, o caso, o objeto em seu contexto, enfim, os aspectos qualitativos do conhecimento. Um questionamento, reconhecemos, poderia ser levantado neste ponto: haveria algum tipo real de contribuição para o avanço da ciência pelas pesquisas conduzidas na vertente do paradigma das "ciências da subjetividade"? Contudo, esta objeção não é tão perturbadora quanto poderia parecer à primeira vista. A perspectiva habermasiana do conhecimento (cf. Carr e Kemmis, 1986) sustenta que diferentes tipos de conhecimento correspondem a (e são, portanto, inseparáveis de) diferentes tipos de interesse social. Uma visão ingênua da ciência identificaria o conhecimento válido com os fins tecnológicos ou instrumentais. Ora, a vida social não consiste somente em aperfeiçoar a relação de controle da natureza pelo homem. Também inclui (e a teoria sócio-cultural da linguagem será a primeira a reconhecê-lo) o aperfeiçoamento das relações sociais - de onde emana o interesse pela ciência como prática de compreensão (interesse interpretativo) e como prática de equacionamento e contestação do exercício do poder (interesse político). Pois bem, se admitirmos (Gee, 1998) que as práticas discursivas, inseparáveis de quaisquer práticas sociais, subsistem como campos de negociação-confirmação de representações e comportamentos, não há meios de conceber uma ciência amputada dos aspectos reflexivo e político da vida social - especialmente hoje, com a derrocada da fé na tecnologia como a cura para os males da humanidade e o decorrente declínio do paradigma iluminista da construção e validação do conhecimento.

\section{O MODELO HOLÍSTICO E O ENSINO DE PORTUGUÊS PARA ESTRANGEIROS}

Obstáculo endêmico na formação continuada, o mal-estar docente tem sido uma constante entre professores de línguas no ensino básico, especialmente em escolas públicas, haja vista a notória e crônica falta de perspectivas quanto ao exercício condigno da profissão, em todos os seus aspectos - não cabe aqui reenumerar o óbvio. E, para agravar ainda mais o quadro, essas mesmas condições contribuem para dificultar sobremaneira as mudanças nas práticas docentes, bem como o trabalho de fundamentação dessas novas práticas, ou seja, a formação de conceitos na esfera profissional.

Contrastando com esse contexto particularmente sombrio para as iniciativas de formação continuada, o ensino de português para estrangeiros (EPLE) oferece um campo ainda não contaminado pelo desalento. Trata-se de um setor não "engessado" em termos curriculares; relativamente aberto à iniciativa dos prestadores de serviços (o EPLE existe na forma de cursos livres); e, talvez o mais importante, não se encontra, no momento, associado a condições aviltantes de exercício profissional. Em decorrência, o mal-estar docente não medra substancialmente nesta especialidade do ensinoaprendizagem de línguas. Tudo isso já propiciaria justificações subjetivas para ações de formação docente.

Mas há, também, razões objetivas para direcionar a pesquisa e a extensão em Letras ao ensino de português para estrangeiros. Dentre elas, a necessidade de qualificar adequadamente professores de PLE em virtude de sua crescente demanda - em parte explicável pela segmentação da economia globalizada em macromercados geopoliticamente regionalizados que fomentam reciprocidades 
mais estreitas (como o Mercosul), sem ignorar as relações com outros países fora do bloco que instituem intercâmbios sócio-econômicos com o Brasil. Em outras palavras, com a crescente importância do EPLE tornam-se oportunos programas de formação inicial e continuada na área, incluindo ensino, pesquisa e extensão. Embora sejam bem-vindas iniciativas locais, a rigor haveria até necessidade de uma verdadeira macropolítica de formação em EPLE nos cursos de Letras das universidades brasileiras. Isto porque o zelo pela profissionalização dos docentes requer não só que o currículo das Letras propicie o indispensável embasamento ao exercício da função na forma de conceitos e práticas didáticas e metodológicas mas também que a Academia contribua para dificultar a invasão do mercado de trabalho por leigos, combatendo o mito de que bastaria ser falante nativo do português para ensinar nosso idioma a estrangeiros.

O Curso de Letras da Universidade Federal de Santa Maria (RS) mantém um Laboratório de EPLE (doravante denominado simplesmente PLE) que promove iniciativas de ensino, pesquisa e extensão na região. O laboratório, além de atender a uma pequena clientela de estrangeiros, principalmente hispanofalantes latinos, também se destina a fornecer subsídios extra-curriculares para a formação inicial nesta especialidade (até o momento optativa) aos alunos interessados. Um dos cursos livres que o PLE vem mantendo na forma de projeto de ensino e extensão é o curso de leitura em português do Brasil para hispanofalantes, que congrega, além do coordenador do presente projeto, uma professora cursando o doutorado no PPGL da UFSM e três acadêmicas exercendo a docência a título de formação inicial. Essa iniciativa procura desenvolver e aperfeiçoar uma metodologia de ensino ao mesmo tempo interativa e intercultural. Caberia aqui perguntar: por que a opção por uma metodologia simultaneamente centrada na interatividade e na intercultura?

Quanto ao interculturalismo, Fleury (1998) e Morin (2000) mostram a importância de um conhecimento mais abrangente e complexo em relação às diferentes culturas encontradas em um ambiente social. Para tanto, Fleury defende que o interculturalismo envolve campos de reflexão e de intervenção que ultrapassam progressivamente o caráter emergencial dos problemas de inserção dos imigrantes e entrou nas temáticas ligadas à formação da identidade, à valorização das diferenças,à configuração e à função que assume hoje o sentido de coletividade em sociedades complexas. Conseqüentemente, no âmbito da atividade formativa e didática devem ser ressaltadas as formas e os conteúdos da cultura interiorizada pelos indivíduos na vida quotidiana, a variedade dos canais e das experiências com que estabelecem contato de acordo com sua posição social e aos modelos culturais que vão elaborando no decurso da vida. Nessa visão, os professores encontrarão na dimensão intercultural condições para promover a autoconsciência e a presença de sujeitos que vivem marginalizados ou possuem outra cultura, bem como amadurecer novos níveis de consciência, focalizando na prática a dialética identidade/diferença.

Bateson (1986), Morin (2000) e Fleury (2003), ao focalizarem os saberes acumulados e seus princípios organizadores, procuram demonstrar, com base num pensamento ecologizante, que o conhecimento progride menos pela sofisticação e abstração dos conhecimentos particulares do que pela aptidão a integrar os conhecimentos em seu contexto global. Para isso, é preciso procurar as relações de reciprocidade entre o todo e as partes, bem como reconhecer a unidade humana nas diversidades individuais e culturais. Nessa perspectiva, o pensamento dialógico a que se refere Morin permite relacionarmos a complexidade nos diferentes tipos de discurso, sejam científicos ou nãocientíficos e os diferentes modos verbal ou não-verbal. Alinhando-se com Bateson, o autor ainda afirma que, entre os seres humanos, esta operação de enquadrar e simbolizar mensagens e ações significativas atinge uma complexidade notável e que precisamos, muitas vezes, nos servir de meios não-verbais, como o gesto, o tom e o contexto.

Já no tocante à interatividade, Moita Lopes declara que, se é através dela que a aprendizagem e o conhecimento são construídos, justifica-se a inclusão nos cursos de formação de professores de estudos que levem à compreensão desse processo, que é mediado pela linguagem. Com relação à 
construção social do significado, ele ocorre na relação entre as pessoas, que quando falam o fazem de algum lugar social específico, baseadas em suas culturas, sendo esse significado afetado pela subjetividade de quem profere o discurso. Desse modo, ao não aceitar as sugestões e opiniões dos alunos, o professor exclui sua participação da construção social do significado. Para o autor o processo de formação de qualquer professor deve incluir, pelo menos, um componente central que focalize a interação e um outro que dê meios para o professor refletir e investigar sua prática.

Em termos de formação inicial de docentes, o ponto de partida típico do trabalho é a insuficiência no trabalho de integração entre teoria e prática. As acadêmicas, uma vez admitidas no PLE para exercer função docente, têm a incumbência de operacionalizar uma abordagem de ensinar LE convertendo-a em uma proposta didática concreta orientada ao contexto, ao longo desta iniciativa extensionista. As acadêmicas-docentes são instruídas a seguir este roteiro de desenvolvimento didático:

I. Levantar o perfil e as necessidades comunicativas e cognitivas da clientela;

II. Conciliar tanto a filosofia de ensino de línguas do laboratório quanto as premissas e prioridades do projeto extensionista com as necessidades dos alunos, estabelecendo assim as metas básicas do curso;

III. No enquadre das metas, subestabelecer os objetivos específicos;

IV. Tendo especificado os parâmetros supramencionados, traçar a proposta didática modular do curso (isto é, o design das unidades de aula);

V. Obter, selecionar e eventualmente editar insumos (input) verbais e não verbais e amalgamá-los com roteiros de tarefas capazes de elicitar produção lingüística (output) discente correspondente ao patamar de desempenho prefigurado em termos dos objetivos específicos já citados;

VI. Prefigurar como um continuum êxito $\Leftrightarrow$ insucesso a relação entre objetivos estipulados e objetivos atingidos, procedendo a um monitoramento constante da qualidade do empreendimento didático (avaliação lato sensu).

Nossa experiência em formação inicial vem atestando que acadêmicas-docentes nessa situação geralmente apresentam dificuldade em equacionar o elenco de suas escolhas didáticas em um esquema global consistente com uma abordagem clara de ensinar-aprender LE e explicável a partir desta. Além disso, ainda não dispõem de bases terminológico-conceituais para conduzir um trabalho mais profícuo de reflexão crítica (evidentemente não só cognitivo, mas também afetivo e comportamental), bases essas indispensáveis para assimilar a experiência reflexivamente organizada a partir da didática.

O acadêmico-docente, não raro, quando desprovido das condições propícias para a formação de conceitos específicos em determinada área da prática pedagógica, tenta eventualmente inovar por simples intuição ou tentativa-e-erro irrefletidamente conduzida. Seu habitus serve de fundo para experimentação baseada em um pretenso saber didático que quase sempre se mostra mais ou menos fragmentário - tanto na relação teoria-prática quanto na arquitetura teórica da abordagem de ensinar adotada (Richter e Moreira, 2004; Richter e Souza, 2004).. Pois bem, essa fragmentariedade não se mostra clara para o estagiário nem mesmo no momento em que é chamado a refletir com colegas, assistido por docentes-supervisores: seu arcabouço conceitual se apresenta nas entrevistas, reuniões, e, por escrito, nos diários conceitualmente pobre, limitando-se a uma espécie de "episodismo" pedagógico. Este é um importante motivo para, em um Modelo Holístico de Formação Docente, reorientar a formação inicial em PLE visando à formação e consolidação de conceitos já nos primeiros contatos com a prática supervisionada.

Vale acrescentar que mesmo as crenças e pressuposições dos alunos-didatas decorrentes de suas experiências pregressas de aluno e, mais recentes em sua história, de professor, não são consideradas na cultura acadêmica como conhecimento válido, visto que dele se espera (tal como ocorre com professores formados) que execute servilmente o que especialistas (vistos como pesquisadores 
que possuem o conhecimento) consideram correto ou conveniente. Paralelamente, no entanto analogamente ao que ocorre com os profissionais graduados, segundo Nutti (op.cit.) - a esse mesmo aluno-professor é que são unilateralmente atribuídas as responsabilidades por problemas ou fracassos no ensino, no momento em que atua. Em decorrência, é possível encontrar estagiários reflexivos utilizando teorias detalhadamente compiladas e justapostas para uso como "escudos" contra fragilidades nas representações (auto-imagens) que fazem de si, do outro (seus alunos, supervisores, pesquisadores) e do(s) contexto(s) (sala de aula, escola, disciplina de formação, currículo de graduação). Logo, também se torna premente trabalhar as representações do imaginário do aluno-docente, para se chegar ao simbólico (valores arraigados) a ponto de repercutir no real (o "corpo", aqui designando o comportamento observável).

E, last but not least, a literatura na área — cf. Almeida Filho e Lombello (1989), Almeida Filho (1993,1995), Moita-Lopes (1995), Júdice (1996), entre outros - parece indicar que o campo sobre formação de professores de PLE ou português como segunda língua está ainda em fase inicial, gradativamente delineado e especificado. Como agravante, um recente levantamento mostrou preocupante escassez de trabalhos voltados especificamente a aspectos de ensino de leitura em PLE. Ora, uma vez que pouco há de relevante até o momento para essa formação, cabe particularmente mais aos graduandos e professores o desafio de construírem um território próprio de saberes teórico-práticos conceitual e terminologicamente sólido.

\section{PREMISSAS METODOLÓGICAS PARA O MODELO}

Como vimos anteriormente, os dados relevantes para se investigar a formação inicial docente são obtidos por meio do Paradigma Indiciário (PI), que seleciona pistas para esse processo instável e não-linear de formação de conceitos sobre ensino de línguas. Porém é preciso também um procedimento cíclico para gerar diários, materiais didáticos e outros que se fizerem necessários - dos quais se obterão os dados a analisar e discutir, a partir do PI. Para tanto, a Pesquisa-Ação (PA) ${ }^{2}$, é adotada no Modelo Holístico na qualidade de abordagem, ou seja, trata-se de um background procedimental que sustenta e garante consistência e integração às práticas extensionistas e investigativas que serão desenvolvidas paralela e imbricadamente no contexto, e das quais se manifestam

2 A pesquisa-ação, segundo Thiollent (1996) e Serrano (1990), procura focalizar problemas de ordem prática colocados pelos envolvidos numa situação específica. Trata-se de procurar soluções para se chegar a alcançar um objetivo ou realizar uma possível transformação dentro da situação observada. Na sua formulação, um problema desta natureza é colocado da seguinte forma:

a) análise e delimitação da situação inicial;

b) delineamento da situação final, em função de critérios de desejabilidade e de factibilidade;

c) identificação de todos os problemas a serem resolvidos para permitir a passagem de A para B:

d) planejamento das ações correspondentes;

e) execução e avaliação das ações.

O problema de transformação colocado como passagem de uma situação inicial para uma situação final ou desejada é definido em função da estratégia ou dos interesses dos atores.

Os temas e problemas apresentados dizem respeito ao contexto da pesquisa voltada para a descrição de situações concretas e para a intervenção ou a ação orientada em função de resolução de problemas detectados. Resumindo alguns de seus aspectos, considera-se que a pesquisa-ação é uma estratégia metodológica da pesquisa social na qual:

a) existe uma ampla e explícita interação entre pesquisadores e pessoas implicadas na situação investigada;

b) desta interação resulta a ordem de prioridade dos problemas a serem pesquisados e das soluções a serem encaminhadas sob forma de ação concreta;

c) o objeto de investigação é constituído pela situação social e pelos problemas de diferentes naturezas encontradas nesta situação;

d) o objeto da pesquisa-ação consiste em resolver problemas ou, pelo menos, em esclarecer os problemas da situação observada;

e) há, durante o processo, um acompanhamento das decisões, das ações e de toda a atividadeintencional do atores da situação. 
ações e reflexões metódicas cujas "pistas" estarão no corpus. Sumariamente, a PA consiste na própria prática social que condiciona e configura os diários e outros materiais de acadêmicos-docentes.

Os diários são analisados, para fins de investigação da formação de conceitos em formação inicial, com base no Paradigma Indiciário. A esse respeito, na literatura há inúmeras teorias referentes ao ensino de línguas, mas a maioria delas não considera o contexto de ensino e a formação de conceitos de ensino dos professores. O Núcleo de Estudos de Conceitos (NEC) da USP desenvolveu recentemente estudos relativos a esse tema, baseando-se principalmente na concepção teórica ou ensiclopédica sobre conceitos. Para o grupo, "um conceito não é uma entidade isolada identificada por um conjunto de propriedades; para além das propriedades, um conceito também constitui-se das relações com outros conceitos, que formam redes ou teorias, as quais, por sua vez, têm cada conceito como elemento constitutivo." (Oliveira,1999:101)

A coordenação de pesquisa investiga linearmente os diários, empregando dados adicionais, se necessário, em função da Tabela 2 (ver adiante), que orienta o controle sobre a formação de conceitos em formação inicial e baseia-se nas teorias sócio-histórica de Vygotsky (a travessia tutorada da Zona de Desenvolvimento Proximal) e cognitiva de Gentner (a construção de modelos por analogia segundo a Teoria do Mapeamento Estrutural). Nesta proposta de trabalho, alunos-docentes se incumbem da elaboração de unidades de um curso matricial de leitura empregando um modelo de curso matricial, centrado em conteúdos de interesse intercultural. Semanalmente, ministram aulas. Quinzenalmente, elaboram diários. Estes são produzidos seguindo roteiros fornecidos por tabelas (ver adiante), assim utilizadas:

I. Ao longo das etapas de produção dos materiais e recursos, acadêmicos-docentes registram as escolhas metodológicas feitas, justificativas teóricas, impasses, expectativas, guiadas pelas tabelas 3 e 4 (ver adiante), esta última limitada aos quesitos-expectativa.

II. Logo após terem ministrado suas aulas, estabelecem aproximações entre os registros da etapa anterior e as observações de aspectos da aula relacionados ao problema que estiverem enfrentando e tentando solucionar por meio das escolhas didáticas realizadas e das estratégias de sala de aula empregadas. Para isso, empregam a tabela 4 , agora na sua totalidade, bem como os quesitosresultado.

III. Os diários analisam-se em gabinete pela coordenação do trabalho de formação inicial, segundo a tabela 1.

IV. Após os resultados na análise, realiza-se uma reunião plenária do grupo de trabalho, orientada pela tabela 5 (ver adiante), para efetuar uma retrospectiva-prospectiva reflexivo-crítica da unidade de curso ministrada, avaliando os níveis epistêmico, deôntico e axiológico das representações dos acadêmicos, procurando monitorar a resolução dos problemas didáticos, a compreensão do processo didático no seu todo (teoria e prática) e a representação que fazem de si, do outro e do contexto.

$\mathrm{V}$. Os procedimentos supracitados repetem-se ciclicamente, segundo a prática consagrada em Pesquisa-Ação.

As tabelas apresentadas abaixo têm a função de propiciar, ao longo dos ciclos de ação-reflexão, dois resultados importantes:

I. Materiais didáticos e diários que possam ser analisados por meio de uma bateria de questões direcionadoras da reflexão;

II. Integração conceitual dos acadêmico-docentes - no sentido de uma maior aproximação teoriaprática, melhorando, assim, a qualidade dos materiais e estratégias de ensino de leitura interativa e intercultural. 


\section{TABELA 1 \\ QUESTÕES PROBLEMATIZADORAS PARA ANÁLISE DO DISCURSO³}

A) CAMPO SEMIOLINGÜÍSTICO 4

\section{- CONFIGURAÇÃO SEMIÓTICA (nível das regularidades formais)}

1. Que sistemas de signos são Relevantes-Irrelevantes (R-I) ${ }^{5}$ para a situação? Como são tornados $R-I$ e de que maneiras?

2. Que sistemas de produção de conhecimentos são Relevantes-Irrelevantes (R-I) para a situação? Como são tornados R-I e de que maneiras?

3. Que linguagens sociais (socioletos) são Relevantes-Irrelevantes (R-I) para a situação? Como são tornados R-I e de que maneiras?6

- CONFIGURAÇÃO EPISTÊMICA (nível das regularidades semânticas)

4. Quais são os sentidos situados (SS) em palavras e enunciados-chave na situação? ${ }^{7}$

5. Que SS e valores parecem vinculados a lugares, momentos, objetos, corporeidades pessoais, artefatos e instituições relevantes à situação?

6. Que modelos culturais e redes de modelos parecem estar integrando mutuamente esses SS?

7. Que Instituições e Discursos estão sendo (re)produzidos nessa situação e como estão sendo estabilizados e transformados na prática intersubjetiva considerada?

- CONFIGURAÇÃO PRÁTICA (nível das regularidades pragmáticas) 8

8. Qual é a atividade (ou grupo de atividades) dominante ou principal na situação?

9. Que subatividades compõem a atividade principal?

10. Que ilocucionários locais ou objetivos locais estruturam e sustentam essas subatividades e atividade (ou grupo de atividades) dominante ou principal? ${ }^{9}$

B) CAMPO HERMENÊUTICO

\section{- CONFIGURAÇÃo IDENTITÁRIA10}

11. Que identidades e relações (IdR) (papéis e posições sociais, com seus componentes pessoal, social e cultural, incluindo crenças - cognição - sentimentos - afetos - e valores - atribuições de qualificativos avaliatórios) parecem relevantes à situação?

12. Como essas IdR são estabilizadas e transformadas na situação?

13. Em termos de identidades, relações sociais e atividades, que Discursos são I-R na situação? Como são tornados R-I e de que maneiras?

- CONFIGURAÇÃo POLÍTICA

14. Que "bens sociais" são (R-I) para a situação? Como são tornados R-I e de que maneiras?

15. Como esses "bens sociais" são vinculados aos modelos culturais e discursivos operantes na situação?

- CONFIGURAÇÃO HISTÓRICO-RELACIONAL

16. Que conexões são feitas ao longo da interação como "fio" da negociação (ou de recusa à negociação) na situação?

\footnotetext{
${ }^{3}$ A metodologia adotada por Gee, enriquecida da Configuração Analógica com Poder Estruturante (CAPE) e das conjecturas analógicas de Guinzburg, segue o Paradigma Indiciário.

${ }^{4}$ Se for incluída, no Questionamento Procedimental (QP), a produção de conhecimento analógico com poder estruturante (CAPE) nos moldes de Gentner, CAPE entrará na Configuração Prática, Configuração Semiótica e Configuração Epistêmica - logo, em todo o campo semiolingüístico.

5 Relevantes-Irrelevantes equivale a Salientes-Não Salientes, ou seja, condição de "pistas deixadas ou colocadas" pelo autor. É em função deste parâmetro que a AD de Gee realiza em Lingüística Aplicada a metodologia do P. Indiciário.

6 Esta questão implicita, no nível formal, as regularidades formais - categoriais, frasais, textuais e estratégicas - das linguagens sociais ou socioletos.

7 Esta questão implicita, no nível semântico, as regularidades categoriais, lexicais, frasais e textuais do texto. Junto com a questão anterior, dá conta, para uma teoria dos gêneros (ACD), da organização retórica, sem necessariamente fazer uso (ou uso completo) de um modelo de descrição de gênero.

8 O Questionamento Procedimental (QP) participa da Configuração Prática.

9 Os objetivos e ilocuções geral e locais, aliados às práticas sociais focadas, determinam a função específica do texto e as subfunções de sustentação ou organização pragmática textual.

10 O modelo mental de D'Andrade estabelece articulação com a Teoria (e Psicologia) Cognitiva e, incluindo o Questionamento de Resolução de Problemas (QRP), participa da Configuração Identitária.
} 
17. Que tipos de conexões são feitas a interações passadas-futuras, outras pessoas, idéias, textos, objetos, instituições e Discursos fora da situação corrente?

18. Como as conexões citadas nas duas perguntas anteriores contribuem, com SS e modelos culturais, para engendrar coerência discursiva - e que tipo de coerência - na situação?

\section{TABELA 2 \\ MACROQUESTÕES INVESTIGATIVAS11}

4. O procedimento $(P)$ é concebido de forma estruturada e apresenta, tanto em $P$ quanto nos componentes de $P$, orientação $O$ (contextualização, justificativa, objetivos e critérios de atingimento) inequívoca? (Saberfazer)

5. A relação $P \Leftrightarrow O$ apresenta-se, tanto em $P$ quanto nos componentes de $P$, consistente? (Saber sobre o saber-fazer)

6. A relação $P \Leftrightarrow O$ apresenta-se, tanto em $P$ quanto nos componentes de $P$, adequadamente representada conceitualmente e explicada? (Saber sobre o saber)

\section{TABELA 3 QUESTIONAMENTO PROCEDIMENTAL (QP) ${ }^{12}$}

1. Que procedimento $(P)$ é esse? Que componentes existem para P? Que componentes de $P$ estão sendo considerados?

2. De que maneira cada componente entra em P? Qual é a função de cada componente em P? Como esse componentes se organizam?

3. A que padrão mais abrangente e superior pertence P? Como estão organizadas as partes no mesmo nível de $\mathrm{P}$ e entre níveis, um dos quais inclui P?

4. Que saberes teóricos e/ou justificativas dão sustentação a P, cada componente e as correlações entre os componentes?

5. Que saberes teóricos e/ou justificativas dão sustentação à escolha de $\mathrm{P}$ e da escolha de cada componente na organização de P?

6. Qual é a meta(s) a alcançar por meio da escolha de $\mathrm{P}$ e da escolha de cada componente na organização de P?

7. Que problema(s) quero solucionar por meio da escolha de P e da escolha de cada componente na organização de P?

\footnotetext{
11 O modelo de Pesquisa-Ação - modificado para o modelo do Diagrama Interpretativo - participa conjuntamente da Configuração Histórico-Relacional e Configuração Prática. O Diagrama Interpretativo adota como modelo de organização de sistemas de representações o Formato Proposicional (FP) utilizado por Reynaldi.

12 Em um programa de formação a distância, o diário datado é elaborado e lançado num site especialmente designado. As fichas devem ser generosamente preenchidas, datadas e reservadas. Para a reformulação cognitivo-afetivocomportamental, após o Chat, o docente emprega (no mínimo) as fichas QP e QRP do início do referido ciclo de Reconstrução de Representações Docentes (inspirado na fusão entre Pesquisa-Ação e Espiral da Complexidade). Para reformular um aspecto problemático considerado Meta - em função de inadequação ou disfunção detectadas, impropriedades conceituais (via leitura) ou reconsideração de relações teórico-práticas (via reflexão intersubjetiva) — o docente utiliza a ficha QP e estabelece nela e a partir dela a modificação no plano de ação a ser executado no ciclo seguinte. $O$ resultado obtido na aula seguinte retroage sobre o conteúdo da ficha e o modifica para o ciclo seguinte e assim sucessivamente. Para um programa presencial, o momento intersubjetivo implica o compartilhamento de reflexões teóricopráticas e eventual assessoria na elaboração de planos de ação didática.
} 
TABELA 4

\section{QUESTIONAMENTO PARA RESOLUÇÃO DE PROBLEMAS (QRP) ${ }^{13}$}

\begin{tabular}{|c|c|c|c|}
\hline \multicolumn{2}{|c|}{$\begin{array}{c}\text { COMPONENTE COGNITIVO-AFETIVO } \\
\text { (percepções, crenças/saberes e sentimentos /emoções) }\end{array}$} & \multicolumn{2}{|c|}{$\begin{array}{c}\text { COMPONENTE AFETIVO-COMPORTAMENTAL } \\
\text { (desejos, intenções e condutas) }\end{array}$} \\
\hline $\begin{array}{l}\text { PROBLEMA } \\
\text { (ou reflexão interciclo) }\end{array}$ & META & INTENÇÃOO & CONDUTA \\
\hline $\begin{array}{l}\text { Como conceituo o pro- } \\
\text { cedimento P }\end{array}$ & Como desejo que seja $\mathrm{P}\left(\Rightarrow \mathrm{P}^{\prime}\right)$ & $\begin{array}{l}\text { Como devo agir para estar } \\
\text { diante de } \mathrm{P}^{\prime}\end{array}$ & $\begin{array}{l}\text { Como espero que trans- } \\
\text { corra a ação - Como } \\
\text { transcorreu efetivamente } \\
\text { a ação } \\
\end{array}$ \\
\hline Como avalio $P$ & \multirow{2}{*}{$\begin{array}{c}\text { Se } P \text { estivesse de acordo com meu } \\
\text { desejo, que situação concreta eu teria } \\
\text { à minha frente }\left(P^{\prime}\right)\end{array}$} & \multirow{2}{*}{$\begin{array}{l}\text { Que plano de ação tenho } \\
\text { para testar para saber se } \\
\text { ele, ao ser executado, me } \\
\text { coloca diante de } \mathrm{P}^{\prime}\end{array}$} & \multirow{2}{*}{$\begin{array}{l}\text { O que espero que resulte } \\
\text { dela }\left(P^{\prime}\right)-O \text { que efeti- } \\
\text { vamente resultou dela: } \\
P^{\prime}, P \text { ou outra }\end{array}$} \\
\hline $\begin{array}{c}\text { Que valores atribuo a } P \\
\text { O que acarreta ou sus- } \\
\text { tenta } P\end{array}$ & & & \\
\hline
\end{tabular}

13 Tabela formulada com base no Modelo da Mente Comum de D’Andrade. O membro transcognoscente da relação intersubjetiva tem como ferramenta auxiliar a tipologia dos Verbos de Atividade Mental de D'Andrade para indiciar nos diários as categorias psíquicas do modelo do autor, na parte superior da tabela. 
TABELA 5

PROTOCOLO SOCIOCOGNITIVO GLOBAL14

\begin{tabular}{|c|c|c|c|c|c|c|c|}
\hline $\begin{array}{l}\text { PARÂMETROS DO } \\
\text { ESQUEMA COGNITI- } \\
\text { VO-AFETIVO- } \\
\text { COMPORTAMENTAL }\end{array}$ & $\begin{array}{l}\text { SITUAÇÃO- } \\
\text { GATILHO }\end{array}$ & $\begin{array}{l}\text { NÍVEL } \\
\text { EPISTÊMI- } \\
\text { CO OPE- } \\
\text { RACIONAL }\end{array}$ & $\begin{array}{l}\text { NÍVEL EPISTÊMICO } \\
\text { REPRESENTACIO- } \\
\text { NAL }\end{array}$ & \begin{tabular}{|l} 
NÍVEL \\
DEÔNTI- \\
CO15
\end{tabular} & $\begin{array}{l}\text { NÍVEL } \\
\text { AXIO- } \\
\text { LÓGI- } \\
\text { co }^{16}\end{array}$ & $\begin{array}{l}\text { AFETIVIDADE } \\
\text { E VALORES }\end{array}$ & CONDUTA \\
\hline $\begin{array}{l}\text { ESQUEMA PROFIS- } \\
\text { SIONAL DISFUNCIO- } \\
\text { NAL: o que de fato } \\
\text { ocorreu automatica- } \\
\text { mente }\end{array}$ & $\begin{array}{l}\text { aspecto } \\
\text { específico } \\
\text { de um pro- } \\
\text { cedimento } \\
\text { de E/A, in- } \\
\text { cluindo in- } \\
\text { teração so- } \\
\text { cial }\end{array}$ & $\begin{array}{|lrr|}\text { o que pas- } \\
\text { sou pela ca- } \\
\text { beça do do- } \\
\text { cente diante } \\
\text { da situação- } \\
\text { gatilho, ao } \\
\text { ser percebi- } \\
\text { da uma mu- } \\
\text { dança } & \text { ou } \\
\text { intensifica- } \\
\text { ção do } & \text { hu- } \\
\text { mor, er } & \text { o } \\
\text { quanto } & 0 \\
\text { docente } & \\
\text { acreditou } \\
\text { nisso } \\
\end{array}$ & $\begin{array}{l}\text { como o docente re- } \\
\text { presenta a si mesmo } \\
\text { no papel que de- } \\
\text { sempenha, seu outro } \\
\text { (colega, aluno, coor- } \\
\text { denador, diretor, } \\
\text { membro da acade- } \\
\text { mia), seu contexto, } \\
\text { seus procedimentos } \\
\text { profissionais e seus } \\
\text { subprocedimentos }\end{array}$ & 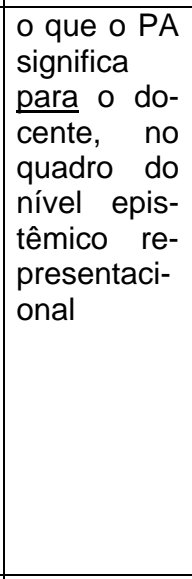 & $\begin{array}{l}\text { o que o } \\
\text { PA si- } \\
\text { gnifica } \\
\text { sobre o } \\
\text { docen- } \\
\text { te, no } \\
\text { quadro } \\
\text { do nível } \\
\text { epistê- } \\
\text { mico } \\
\text { repre- } \\
\text { senta- } \\
\text { cional }\end{array}$ & $\begin{array}{l}\text { que afetos ou } \\
\text { valorações (in- } \\
\text { clusive do pró- } \\
\text { prio docente) } \\
\text { acometeram o } \\
\text { docente, e em } \\
\text { que grau }\end{array}$ & $\begin{array}{l}\text { como o do- } \\
\text { cente aca- } \\
\text { bou por se } \\
\text { conduzir, } \\
\text { uma vez } \\
\text { acometido } \\
\text { dos PAs e } \\
\text { emoções } \\
\text { concomi- } \\
\text { tantes e que } \\
\text { Estratégias } \\
\text { Compensa- } \\
\text { tórias po- } \\
\text { dem estar } \\
\text { subjacentes } \\
\text { a isso } \\
\end{array}$ \\
\hline $\begin{array}{l}\text { ESQUEMA PROFIS- } \\
\text { SIONAL ADEQUADO: } \\
\text { o que estava para } \\
\text { ocorrer segundo um } \\
\text { plano de ação ou } \\
\text { conforme um desejo }\end{array}$ & $\begin{array}{l}\text { aspecto es- } \\
\text { pecífico de } \\
\text { um proce- } \\
\text { dimento de } \\
\text { E/A, incluin- } \\
\text { do interação } \\
\text { social }\end{array}$ & $\begin{array}{l}\text { o que o do- } \\
\text { cente acha } \\
\text { que deveria } \\
\text { passar por } \\
\text { sua cabeça } \\
\text { diante da } \\
\text { situação- } \\
\text { gatilho, após } \\
\text { controle de } \\
\text { evidências } \\
\text { contra ou a } \\
\text { favor dos } \\
\text { PAs }\end{array}$ & $\begin{array}{l}\text { como o docente acha } \\
\text { que deveria recon- } \\
\text { ceituar ou reimaginar } \\
\text { os componentes do } \\
\text { exercício profissio- } \\
\text { nal, em função da } \\
\text { correção de inade- } \\
\text { quações }\end{array}$ & \begin{tabular}{|l|} 
(discutir \\
com a \\
equipe que \\
técnicas \\
auxiliares \\
podem \\
eventual- \\
mente ser \\
usadas \\
para a re- \\
estrutura- \\
ção de \\
crenças \\
intermediá- \\
rias) \\
7
\end{tabular} & \begin{tabular}{|l} 
discutir \\
com a a \\
equipe \\
que \\
técnicas \\
auxilia- \\
res po- \\
dem \\
eventu- \\
almente \\
ser \\
usadas \\
para \\
modifi- \\
car \\
crenças \\
centrais \\
\end{tabular} & $\begin{array}{l}\text { que afetos ou } \\
\text { valorações (in- } \\
\text { clusive do pró- } \\
\text { prio docente) } \\
\text { este crê que o } \\
\text { acometeriam } \\
\text { se o PA fosse } \\
\text { falso } \\
\text { ( = Resposta } \\
\text { Adaptativa) }\end{array}$ & $\begin{array}{l}\text { como o do- } \\
\text { cente pre- } \\
\text { tende ter-se } \\
\text { conduzido, } \\
\text { na hipótese } \\
\text { de que o PA } \\
\text { fosse falso } \\
\text { (conduta } \\
\text { profissional } \\
\text { compatível } \\
\text { com a Res- } \\
\text { posta } \\
\text { Adaptativa) }\end{array}$ \\
\hline
\end{tabular}

14 Esta tabela servirá de base (auxiliada pelas fichas de QP e QRP e os diários) para a reflexão intersubjetiva de docentes, com base na Sociocognição Modificadora, e já incorpora, entre outras contribuições, tanto a técnica da flecha descendente quanto o registro de pensamentos disfuncionais. Infelizmente, para um programa de construção de conceitos em formação continuada de docentes, a Terapia Cognitiva Padrão apresenta a desvantagem da TRIVIALIZAÇÃO do espaço de problematização (ou seja, não são focalizadas e tratadas questões ou metas que digam respeito às condições de exercício de uma competência social stricto sensu - são levados em conta problemas meramente de senso comum). Daí a necessidade de adaptações profundas.

A situação-gatilho e a conduta devem ser descritas empregando um discurso preferencialmente "fundado" em conceitos de âmbito profissional por meio do QP e em seguida "preparado" com o QRP para, após "parametrizar" as reflexões, confirmar/refutar/reformular quaisquer aspectos da cognição, afetividade e conduta profissional (FUNDAÇÃO $\Rightarrow$ PREPARAÇÃO $\Rightarrow$ PARAMETRIZAÇÃO $\Rightarrow$ RETIFICAÇÃO). Esse encadeamento reflexivo-crítico tem por finalidade contrapor-se à trivialização da TCC e elicitar a experimentação de uma lógica profissional dos acontecimentos. As metas devem ser focais e graduais na formação continuada.

15 De acordo com a Terapia Cognitiva, engloba apenas regras e relações condicionais que, ou tentam compensar uma inadequação específica com um "bom comportamento", ou sentenciam uma condição socialmente ameaçadora para o sujeito.Porém, dentro da visão da $A D$, é indispensável fazer preceder esse questionamento pela investigação das Representações Subjacentes do Sujeito-Docente, do Outro (Colega, Aluno, Coordenador, Diretor) e do Procedimento Didático (Nível Epistêmico Representacional). A partir destas, se inferem os já citados conteúdos da TC.

16 Mais exatamente: ou o docente se atribui uma situação de desamparo (não se sentir capaz de fazer algo ou de fazê-lo corretamente), ou uma situação de exclusão (não aceitação pelo outro).

17 Caso se mostre oportuno, pode ser discutida com a equipe a aplicação de estratégias de interferência nas crenças, já consagradas em Terapia Cognitiva, tais como Metáforas, Role-Play, Cartões de Enfrentamento, Reestruturação de Esquemas Cognitivos Antigos, Problem-Solving. 


\section{BIBLIOGRAFIA}

ABDALLAH-PRETCEILLE, Martine;PORCHER,Louis. Educacion et communication interculturelle. Paris: PUF,1996.

ALMEIDA FILHO, J.C.P., LOMBELLO, Leonor C. (orgs). 0 ensino de português para estrangeiros. Campinas, SP: Pontes, 1989.

Dimensões Comunicativas no Ensino de Línguas. Campinas: Pontes Editores, 1993.

Crises, Transições e Mudanças no Currículo de Formação de Professores de Línguas. Mimeo.

Tendências na Formação Continuada do Professor de Língua Estrangeira. Mimeo. Campinas: UNICAMP, 1995.

BATESON, Gregory. Mente e Natureza: a unidade necessária. Trad. Cláudia Gerpe. Rio de Janeiro: Francisco Alves, 1986.

BARONE, Leda Maria. De ler o desejo, ao desejo de ler: uma leitura do olhar do psicopedagogo. Petrópolis: Vozes, 1993.

BYRAM, Michael. Culture et éducation en langue étrangère. Paris: Didier,1992.

BROWN, H .Douglas. Readings on Second Language Acquisition. Englewood Cliffs: Prentice Hall, Regentes, 1995. 1995.

Principles of language, learning and teaching. Englewood Cliffs: Prentice Hall, Regents,

Teaching by principles: an interactive approach to language pedagogy. New Jersey: Prentice Hall, Regentes, 1994.

CABRAL, Leonor Scliar. Narrativa em criança e os processos de leitura. Florianópolis: UFSC; 1983.

CADERNOS DO CENTRO DE LÍNGUAS. Ensino de Português língua estrangeira. São Paulo, USP, Humanitas, 1997.

CALDERHEAD, J. : Teacher's Professional Learning. The Falmer Press. Great Britain, 1988

CAVALCANTI, Marilda do Couto. Interação leitor-texto: aspectos de interpretação pragmática. Campinas: UNICAMP, 1989.

CAVALCANTI, M.C. e MOITA LOPES, L. P. da. Implementação de Pesquisa na Sala de Aula de Línguas no Contexto Brasileiro. In Trabalhos de Lingüística Aplicada, Campinas (17).Jan/jun, 1991, pp 133-144.

CHARTIER, Roger. Práticas da leitura. São Paulo: Estação Liberdade, 1996

CHIMIM, Renata. 0 fazer, o saber e o ser: reflexões de/sobre professores de inglês de uma escola de idiomas. São Paulo: Pontifícia Universidade Católica, Dissertação de Mestrado, 2003.

COELHO, Jacinto do Prado et al. Problemática da leitura: aspectos sociológicos e pedagógicos. Lisboa: Instituto Nacional de Investigação Científica, 1980.

COLLINS, Alan; GENTNER, Dedre. How peopel construct mental models. In: QUINN, Naomi; HOLLAND, Dorothy. Cultural Models in Language and Thought. Cambridge: Cambridge UniversitY Press, 1987.

CORACINI, Maria José. Análise do discurso: em busca de uma metodologia. Revista D.E.L.T.A., v.2, n.1, 1991.

Maria José. 0 jogo discursivo na aula de leitura: língua materna e língua estrangeira. Campinas: Pontes, 1995.

CLARK, C.M. e PETERSON, P.P. Teacher's thought Processes. In: Merlin C. Wittrock: Handbook of Research on Teaching, 3a. edição. New York: Collier Macmillan Publishers, 1986.

D'ANDRADE, Roy. A folk model of the mind. In QUINN, Naomi; HOLLAND, Dorothy. Cultural Models in Language and Thought. Cambridge: Cambridge University press, 1987.

ECO, Umberto. Semiótica e Filosofia da linguagem. São Paulo: Ática,1991. 
Encontro Nacional de Didática e Prática de Ensino (ENDIPE). Ensinar e aprender: sujeitos, saberes e pesquisa. Rio de Janeiro: DP\&A, 2000.

Ensino de Português Língua Estrangeira. São Paulo: Humanistas Publicações FFLCH/USP, 1997.

Ensino de Português para Estrangeiros: Ciclo de Palestras. Niterói: EDUFF, 1997.

FARNHAM-DIGGORI, Sílvia. Cognitive process in education. Nova York: Harper Collins, 1992.

FIGUEIREDO, F. J. Q. Aprendendo com erros: uma perspectiva comunicativa de ensino de línguas. Goiânia: UFG, 1997.

FLETCHER, Paul, GARMAN, Michael.2 $2^{a}$ ed. Language acquisition. USA: Cambridge University Press, 1997.

FLEURY, Reynaldo Matias (org). Intercultura e Movimentos sociais. Florianópolis: MOVER/NUP, 1998.

FLEURY, Reynaldo Matias. Multiculturalismo e interculturalismo nos processos educacionais. Disponível em: www.ced.ufsc.br/nucleos/mover/. Acesso em 28 de agosto de 2003.

Educação intercultural e complexidade. Disponível em: www.ced.ufsc.br/nucleos/mover/. Acesso em 28 de agosto de 2003.

Desafios à educação intercultural no Brasil: culturas diferentes podem conversar entre si? Disponível em: www.ced.ufsc.br/nucleos/mover. Acesso em 28 de agosto de 2003.

Educação popular e complexidade: novos olhares, novas questões. Disponível em: www.ced.ufsc.br/nucleos/mover/. Acesso em 28 de agosto de 2003.

FREEMAN, D. e RICHARDS, J.C.: Conceptions of Teaching and Education of Second Language Teachers. In Tesol Quartely, vol. 27, nํ2, Summer, 1993.

GENTNER, Dedre et al. Metaphor is like analogy. In: Gentner, D., Holyoak,K.J.; Kokinov, B.N. (eds). The analogical mind: perspectives from cognitive science. Cambridge MA: MIT Press, 2001.

GENTNER, Dedre; MEDINA, José. Similarity and the development of rules. In: Cognition 65 . Elsevier Science, 1998.

GENTNER, Dedre; NAMY, Laura L. Comparision in the development of categories. In: Cognitive Development 14. 1999.

GENTNER, Dedre; WOLLF, Phillip. Metaphor and Knowledge change. In: Cognitive dynamics: conceptual changes in humans and machines. Mahwah, NJ: Lawrence Eribaum Associates. 1999.

GERARDI, J. W. Linguagem e ensino: exercícios de militância e divulgação. Campinas, SP: Mercado de Letras - ABL, 1996.

O texto na sala de aula: leitura e produção. Cascavel: ASSOESTE, 1984.

GIMENEZ, Telma N. Learners becoming Teachers. Dissertação de Doutorado. Lancaster University, 1994.

IRWIN, Judith W. ; DOYLE, Mary Anne. Reading/Writing connections: learning from research. Nova York: International Reading Association, 1992.

JÚDICE, Norimar (org. et al). O ensino de Português para estrangeiros. Niterói, EDUFF, 1996.

KATO, Mary. No mundo da escrita: uma perspectiva psicolingüística. São Paulo: Ática,1986.

. O aprendizado da leitura. São Paulo: Martins Fontes, 1985

KLEIMAN, Angela B. Texto e leitor: aspectos cognitivos da leitura. Campinas: Pontes, 1989.

. Leitura, ensino e pesquisa. Campinas: Pontes,1989.

Oficina de leitura: teoria e prática. Campinas: Pontes, Unicamp, 1992.

$\mathrm{KOCH}, \mathrm{I}$. V. O texto e a construção dos sentidos. São Paulo: Contexto, 1997.

KORTHAGEN, F.A.J.: The Influence of Learning Orientations on the Development of Reflexive Teaching. In J. CALDERHEAD: Teacher's Professional Learning. The Falmer Press. Great Britain. 1988, Capítulo 2, pp. 35-50.

KRAMSCH, Claire. The cultural component of language teaching. Disponível em: www.spz.tudarmstadt.de/projekt ejournal/jg 01 2/beitrag/kramsch2.htm Acesso em 26 de maio de 2003.

KRASHEN, Stephen D. Principles and second language acquisition. California, Pergamon, 1987. 
LARSEN-FREEMAN, Diane, LONG, Michael H. An introduction to second language acquisition research. New York: Longman, 1991.

LEITCH, Ruth; DAY, Christopher. Action research and reflective practice: towards a holistic view. In: Educacional Action Research, Vol. 8, № 1, 2000.

LIBERALLI, Fernanda C. 0 diário como ferramenta para a reflexão crítica. São Paulo: Pontifícia Universidade Católica, Tese de Doutorado, 1999.

LIGHTBOWN, Patsy M., SPADA, Nina. Second Language Learning in the Classroom. In: How Languages are Learned. Oxford: Oxford University Press, 1993, pp 69-110.

LIMA, João F. Lopes. Reconstrução da tarefa educativa: uma alternativa para a crise e a desesperança. Porta Alegre: Mediação, 2003.

LOMBELLO, Leonor C. (orgs). Identidade e caminhos no ensino de Português para Estrangeiros. Campinas: Pontes, 1992.

LURIA, Alexander R. Desenvolvimento cognitivo: seus fundamentos culturais e sociais. São Paulo: Ícone, 1990.

MARCHANT, M. Português para estrangeiros. Porto Alegre: AGE, 1995.

MESERANI, Samir. O intertexto escolar: sobre leitura, aula e redação. São Paulo: Cortez, 1995. MOITA LOPES, L. P. da: Interação e Aprendizagem de Leitura em Sala de Aula de Língua Estrangeira e Materna na Escola Pública. In Moita Lopes, L.P. \& Molicca, M.C.(org.): Espaços e Interfaces da Língüística e da Lingüística Aplicada. Cadernos Pedagógicos, no 17. Rio de Janeiro: UFRJ, 1995.

MOITA LOPES, L. P. da. Linguagem/Interação e Formação do(a) Professor(a). Programa de Lingüística Aplicada da Universidade Federal do Rio de Janeiro, 1996.

MORAES, M.G.D.V.: Contribuições da Pesquisa na Sala de Aula de Línguas para a Formação do Professor de Língua Estrangeira. In Contexturas. Ensino Crítico de Língua Inglesa, no 1. APLIESP, 1992.

MORIN, Edgar. A cabeça bem feita. Rio de Janeiro: Bertrand Brasil, 2000.

MORIN, Edgar. Os sete saberes necessários à educação do futuro. São Paulo: Cortez, 2000.

MOURA, Patrícia Mayra. A organização conceitual em adultos pouco escolarizados. In Oliveira Marcos e Oliveira Marta (orgs). Investigações Cognitivas. Porto Alegre. Artes médicas. 1999.

NEWSCOMBE, Nora. Linguagem e comunicação. In: Desenvolvimento Infantil. Porto Alegre, Artes Médicas. P. 210 - 239, 1999.

NUNAN, David \& LAMB, Clarice. The self-directed teacher: managing the learning process. USA, Cambridge University, 1996.

NUNAN, David. Research methods in language learning. New York: Cambridge University Press, 1992.

NUTTI, JULIANA Z. Dando voz aos professores: breve panorama das tendências atuais na pesquisa sobre a formação e atuação docente. Psicopedagogia on line. Publicado em 19.10.2002. URL: www.psicopedagogia.com.br/artigos/artigo.asp?entrlD=375

OLIVEIRA, Marta Kohl. Vygotsky: aprendizado e desenvolvimento um processo sóciohistórico. São Paulo, Scipione, 1995.

OLIVEIRA, Marcos B; OLIVEIRA, Marta K. (orgs). Investigações cognitivas. Porto Alegre: Artes Médicas, 1999.

Parâmetros Curriculares Nacionais: pluralidade cultural e orientação sexual/ Secretaria de Educação Fundamental. Brasília:MEC/sef, 1997

PÉREZ GÓMEZ, A. O pensamento prático do professor: a formação do professor como profissional reflexivo. In: NÓVOA, A.(Org.) Os professores e sua formação. Lisboa: Dom Quixote, 1995.

PERRENOUD, P. Práticas pedagógicas, profissão docente e formação - perspectivas sociológicas. Lisboa: Dom Quixote, 1997.

REYNALDI, Maria Ângela A. C. A cultura de ensinar língua materna e língua estrangeira em um contexto brasileiro. Campinas: IEL-UNICAMP, Dissertação de Mestrado, 2003. 
REYNALDI, Maria Ângela Abbade Chimelo. A cultura de ensinar língua materna e língua estrangeira em um contexto brasileiro. São Paulo. USP. 1999 Dissertação de mestrado.

RICHARDS, Jack C. \& KATO, Mari A. (org) Português brasileiro: uma viagem diacrônica. Campinas, SP, Ed. Unicamp, 1993.

RICHTER, Marcos G. Ensino do português e interatividade. Santa Maria: Ufsm, 2000.

SERRANO, Maria Glória Perez. Investigación-acción: aplicaciones al campo social y educativo. Madrid: Dykinson, 1990.

SILVA, Ezequiel Theodoro da. Os (des) caminhos da escola: traumatismo educacionais. São Paulo: Cortez, 1981.

SILVEIRA, Regina Célia P. da (org). Português língua estrangeira: perspectivas. São Paulo: Cortez: 1998.

SCARAMUCCI, M.V.R.: O projeto CELPE-BRAS no âmbito do Mercosul: Contribuições para uma Definição de Proficiência Comunicativa. In J.C.P.Almeida Filho (org): Português para Estrangeiros: Interface com Espanhol. Campinas: Pontes, 1995a, pp 77-90.

TRIVINÕS, Augusto N. S. et al. A formação do educador como pesquisador no Mercosul/Cone Sul. Porto Alegre: Editora da UFRGS, 2003.

THIOLLENT, Michel. Metodologia da pesquisa-ação. São Paulo: Cortez,1996.

VóVIO, Cláudia Lemos. Duas modalidades de pensamento: pensamento narrativo e pensamento lógico-científico. In Oliveira Marcos e Oliveira Marta (orgs.). Investigações Cognitivas. Porto Alegre. Artes médicas.1999.

VYGOTSKY, L.S. Pensamento e Linguagem. São Paulo: Editora Martins Fontes, 1991.

A formação social da mente: o desenvolvimento dos processos psicológicos superiores. São Paulo: Martins fontes, 1994.

VIGOTSKY, Lev S., LURIA, Alexander R., LEONTIEV, Alexis N. Linguagem, desenvolvimento e aprendizagem. São Paulo: Ícone, 1992.

WIDDOWSON, Henry G. O ensino de línguas para a comunicação. Campinas: Pontes, 1991.

ZARATE, Geneviève. Einseigner une culture étrangère. Paris: Hachette, 1986.

ZARATE, Geneviève. Répresentations de l'etranger et didactique des langues. Paris: Didier, 1993. 